\title{
Genetic fallout in bio-cultural landscapes: Molecular imperialism and the cultural politics of (not) seeing transgenes in Mexico
}

\author{
Christophe Bonneuil- Centre A. Koyré, Cnrs-Ehess, Paris, France \\ Jean Foyer - Institut des Sciences de la Communications, CNRS, Paris, France \\ Brian Wynne - Department of Sociology, Lancaster University, Lancaster, UK
}

Article published in Social Studies of Sciences, 44(6), 2014, 901-929

\begin{abstract}
This article explores the trajectory of the global controversy over the introgression (or not) of transgenes from genetically modified maize into Mexican indigenous maize landraces. While a plurality of knowledge-making processes were deployed to render transgenes visible or invisible, we analyze how a particular in-vitro based DNA-centred knowledge came to marginalize other forms of knowledge, thus obscuring other bio-cultural dimensions key to the understanding of gene flow and of maize diversity. We show that dominant molecular norms of proof and standards of detection, which co-developed with the world of industrial monocropping and gene patenting, discarded and externalized non-compliant actors (i.e. complex maize genomes, human dimensions of gene flow). Operating in the name of highscience, they hence obscured the complex biological and cultural processes that maintain crop diversity and enacted a cultural-political domination over the world of Mexican landraces and indigenous communities.
\end{abstract}

\section{Keywords}

Epistemic cultures, co-production, legibility-illegibility, normalization, lab-field relations, GMOs, maize biocultures, Mexico's indigenous landraces.

\section{Corresponding author}

Christophe Bonneuil. Centre A. Koyré (Cnrs-Ehess-MNHN). 27, rue Damesme. 75013 Paris. France

Email: christophe.bonneuil@cnrs.fr 


\section{Introduction}

In 2001, an article in the journal Nature by David Quist and Ignacio Chapela reported scientific findings of transgenes that had escaped from genetically modified (GM) maize and introgressed into Mexican indigenous maize landraces (Quist and Chapela, 2001). This news came a few months after reports that thousands of truckloads or railcars of unauthorized StarLink GM maize for human food in the US had been contaminated. In just four days, the Starlink contamination case was confirmed and provoked thoroughgoing action, including a huge compensation bill and the recall of hundreds of product lines (Lezaun, 2003). The Nature findings were highly unwelcome to the Mexican government, which had established a moratorium on transgenic maize planting in Mexico in 1998, as well as to GM commercial interests, which claimed GM crops were both safe and containable. The findings suggested that no remote place could escape uncontrolled transgene fallout, and highlighted the new, uncharted transnational artificial genetic landscapes created by the global agricultural biotechnology enterprise.

The Mexican GM maize issue was a resoundingly global controversy. Mexico is a global centre of origin and ongoing diversification of maize, and its maize landraces constitute a genetic pool seen as critical for the future of international crop-breeding and food security. The controversy connected small farming communities with international arenas and biotech laboratories, and raised pressing issues over indigenous peoples' rights, farmers' livelihoods, neoliberal globalization, biological and cultural diversity and the commoditization of life (Foyer, 2010; Wainwright and Mercer, 2011; Kinchy, 2012). However, although socioenvironmental groups have striven to foreground these political, cultural and economic issues, the GM maize controversy has been 'scientized' and channeled into narrowly technical 'risk' and 'detection' framings (Kinchy, 2012; Wynne 2001). In this paper, we show how the technoscientific culture given sovereignty in this controversy, molecular biology and DNAbased GM detection, enacted much more than a specific, solely technoscientific analytical cut. This technoscientific culture embodied and projected an extensive and powerful framing which performed a particular political-economic and cultural normativity by denying recognition to other key biological and human dimensions of Mexican maize.

The first publication reporting the presence of transgenes in Mexican landraces (Quist and Chapela, 2001) was immediately strongly attacked (see Delborne, 2008). The next peerreviewed publication (Ortiz-García et al., 2005) reported no transgenes in samples from the same region, providing reassurances that were widely publicized, that no transgenes existed in Mexican maize. It was not until 2007-2009 that further positive findings, which since 2001 had multiplied and circulated in non-peer-reviewed reports and unpublished documents, were published in peer-reviewed scientific journals (Serratos et al., 2007; Piñeyro-Nelson et al., 2009a; Dyer et al., 2009). In an age of high-throughput post-genomics, eight years to confirm the presence of transgenes in analytical samples is a surprisingly long time. 
Our inquiry starts from this basic question: Why did it take four days to confirm the presence of unauthorized GM maize and undertake costly remedial action in the case of StarLink in the US, yet many years to do the same in Mexico? This situation warrants a closer look at sociotechnical processes that turn, or fail to turn, invisible transgene flows into evidence of 'contamination.' We argue that a key element in the Mexican controversy is that a particular scientific subculture, molecular biology, with its taken-for-granted epistemic norms stretching far beyond the laboratory, gained global authority over what constituted good evidence. The apparently purely technical issues of transgene-detection embody much larger issues of political and cultural asymmetries of power, abetted systematically through science.

The point that knowledge often involves making invisible phenomena visible, bringing them to produce recognizable and repeatable signs, traces and tracks, has become normal currency of STS work. However, its corollary, that such knowledge-production and its renderings of visibility also perform a corresponding rendering of other forms of invisibility, or nonknowledge, has only come to the fore more recently, to further elaborate on sociology of scientific knowledge in public arenas. A key dimension of both these forms of epistemic ordering to produce forms of invisibility as well as visibility, is that these ordering processes occur through mutual ordering, or co-production, with corresponding orders of social practices and relations (Jasanoff, 2004). How can invisible transgenes be turned into visible signals that unmask their presence within local maize landraces? In Mexico, there were multiple knowledge-making processes available for rendering transgenes visible or invisible. But only the DNA-based approach that used state-of-the-art PCR was deemed a worthy basis for articles published in top international scientific journals. This reflected (and reinforced) the hegemony of molecular biology, which focused on laboratory practices of molecular control and reduced its intellectual frame to only those factors which were amenable to such control, while non-compliant actors, non-human or human, were discarded and externalized.

Our paper analyzes key beliefs, norms and commitments embodied in the technical standards granted privilege to adjudicate the controversy. Those technical standards also embody commitments that impose normative structure far beyond the laboratory alone, as we see later, for example with their neglect of important differences of genome-structure between modern hybrid and indigenous maize varieties. In shaping what is counted as normal, these commitments also implicitly perform a particular worldview, reinforcing or co-producing a dominant political and social order. The technoscientific culture of molecular biology thus enacted a domination not only over Mexican indigenous farming cultures, but also over other salient epistemic cultures, such as population genetics, agroecology and anthropology. This paper shows how such dominations: obscured the complex bio-cultural processes that maintain crop diversity; delegitimized farmers' agro-ecological knowledge and forms of life; and threatened the very processes that maintain biodiversity. 
The first section of the paper introduces our theoretical perspective. The second sketches the trajectory of the controversy. In the third, we explore the plurality of knowledge-making processes deployed to render transgenes visible or invisible, and show how a particular invitro based DNA-centered knowledge came to marginalize other forms of knowledge, and to obscure bio-cultural dimensions of gene flow and crop genetic diversity. The fourth section examines the tensions between the standardizing gaze of (commercial) PCR detection, and the fluid and heterogeneous Mexican landrace maize genomes. We conclude by discussing how dominant molecular norms of proof and standards of detection embody a cultural-political domination over the bio-cultural world of Mexican landraces and the indigenous communities that cultivate them.

The paper is based on interviews (some repeat visits) with about thirty key scientific and policy protagonists, as well as related peer-review reports and correspondence. We also make use of unpublished material, obtained from our informants, that allowed us to document all the sampling surveys and almost all the manuscripts on this issue submitted to scientific journals between 2000 and 2009.

\section{The STS of not seeing}

Given the inevitably selective processes that order scientific knowledge cultures, each 'epistemic culture' (Knorr-Cetina, 1999) has its own distinct practices of producing and dealing with non-knowledge. Several discussions from STS illustrate the point, and can be taken to suggest that the very productivity and power of technoscientific standards may be quintessentially what also produces invisibility of non-standard actors, both human and nonhuman. Kleinman and Suryanarayanan (2012) describe the normative knock-on effects of particular epistemic cultures as multi-layered: the effects range and graduate over time and routinization, from explicit choices to the naturalized practices of encultured techno-scientific paradigms. They come to embody normative 'choices' constitutionally (Jasanoff, 2011). Such normative standards - which structure, extend and empower each technoscientific paradigm - can exclude and effectively delete salient variables and conditions that happen to be noncompliant with the standard's normative gaze. This occurs both within and beyond the domain itself, depending on perceived reach into applied worlds. Busch (2011) has also delineated this ambivalent property of the normativity of technoscientific paradigms in his analysis of standards and certification schemes, as have Waterton and Wynne (1998) in their treatment of more overt policy standards. Mackenzie et al. (2013) have extended the discussion into the broad 'lively' domain (Sunder Rajan, 2013) of life sciences and related forms. Here especially, aims to standardize encounter a teeming variety of exuberantly emergent forms of non-compliance. 
With respect to agricultural GMOs and their potential impacts, Böschen et al. $(2006,2009)$ and Bonneuil (2006) have identified contrasting and competing interactive epistemic cultures, such as molecular biology, ecology and systems agronomy. These authors have shown that molecular biology is distinguished from related scientific specialties by its characteristic function, including its research objects (the gene as a commanding molecule in the programmable cell-factory, as distinct from being in flux in meta-populations and ecosystems), epistemic objects, scales and units of analysis, methods of producing data, ways of constructing explanations, framing of risks and attitudes to unknowns. Each function determines what is relevant or irrelevant to the epistemic project, and also contributes to bringing into being and consolidation of a corresponding human-cultural order.

The epistemic culture of molecular biology is notable with respect to its culture of nonknowledge. Through her ethnographic work with the contrasting epistemic cultures of highenergy physics and molecular biology, Knorr-Cetina (1999) demonstrated that the latter is far less engaged with the limits and boundaries of its own knowledge. High-energy physics is attentive to such limits as disturbances, errors, unexpected events and uncertainties. However, molecular biologists seldom explore possible unknowns when an experiment fails or delivers unforeseen results. Instead they tend to vary the conditions of the experiment until the expected outcome emerges, a heuristic strategy that Knorr-Cetina calls 'semi-blind variation' (Knorr-Cetina, 1999: 110).

In the case of the Mexican GM maize controversy, epistemic culture is an analytic that helps to illustrate the relationships between molecular biology's particular understanding of (trans)gene flow and understandings of other, marginalized, epistemic cultures, such as (agro)ecology, population biology, or anthropology of farmers' seed practices). In this case, molecular biology's claim to sound science involved invocation of stringent norms of proof for detecting transgenes, while strategies such as semi-blind variation provided normative force to exclusion of uncertainties, anomalies, non-standard forms, and complexities. Attention to this culture of non-knowledge sheds light on how the controversy involved blindness to the dynamics and natural-cultural hybridities of maize genomes that have evolved over centuries in Mexican landscapes.

There is a useful complement to the epistemic cultures perspective in Proctor and Schiebinger's (2008) analysis of the production of scientific 'ignorance' as social practice. Proctor and Schiebinger identify multiple kinds of ignorance. One kind, that which is actively and strategically fabricated, have been well documented in the Mexican GM maize controversy (Delborne, 2008; Foyer, 2010; Kinchy, 2012). Indeed, in his analysis of the first year of the controversy, Delborne (2008) speaks to the intensive deployment of strategically fabricated ignorance in terms of 'epistemological tyranny of the intellectual majority' and the 'institutional majority'. However, Proctor and Schiebinger outline another highly relevant yet less discussed kind of ignorance, the effect of framing (Wynne, 1989, 1992) - to focus on this 
as salient is inevitably to ignore that, possibly without even knowing that one has made that 'choice.' This selective ignorance is embodied in paradigms, or epistemic cultures, that always articulate theoretical, material and social options in ways that neglect phenomena outside of their scope. Ignorance as an effect of framing is an issue in the controversy over Mexican GM maize, because the framings privileged by the scientific journals were orchestrated by a set of technoscientific mechanisms that selected who and what were, or were not, relevant and meaningful. These included: a selective set of questions, a selective set of data, a selective set of technical skills to create and interpret correspondent data, specific sources of knowledge and information, and specific norms of proof.

These selective framings also embodied particular epistemic-cultural beliefs and commitments: that the knowledge produced by molecular biology is universally superior to knowledge produced by farmers, agronomy, ecology, population genetics and anthropology; that the laboratory and the molecular scale, not the field, is the relevant locus for sound science; and that a few genetically homogeneous cultivars designed for global markets and their infrastructures can adequately represent, genomically and politically, Mexico's complex maize bio-cultural landscape. These epistemic norms resonate with a political economy in which agriculture oriented to global markets competes on unequal terms with indigenous maize biocultures.

In the Mexican GM maize controversy, the beliefs and norms of the epistemic culture of molecular biology gained force from two related processes. First, there was a chain of extraction, reduction and translation that allowed signs observed on gels in labs to speak for the distant presence or absence of transgenes in fields. And second, there was a purification and standardization in the laboratory micro-world, which was materially and symbolically projected onto the diverse, fluid and extensive macro-worlds of indigenous maize. ActorNetwork Theory (ANT) has contributed much to the understanding of these types of processes. For example, Latour (1995) analyzes the production of stable networks across innumerable transfer-situations. Much scientific effort aims to produce conceptual and material objects that remain stable from field to laboratory and back (Callon et al., 2009, 4868). These immutable mobiles differ from fuzzy objects that would lose their salient properties when displaced. Once purified and disciplined in the laboratory, immutable mobiles are projected back into field situations, reordering them according to laboratory standards. In this controversy however, there was also the key mediating role of international scientific journals in giving sole authority to a molecular framing of the issue.

Twentieth century genetics and molecular biology have constituted the cultivar and the gene as immutable mobiles - objects of exact science, modernization policies and global trade (Bonneuil, 2014; Fox-Keller, 2000). Van der Ploeg (1993) offers a powerful anthropological study of such constitutive processes in another center of origin agriculture, indigenous Andean potato-farming. The study illustrates how modernizing agricultural experts and 
institutions promoted a singular laboratory-optimized genotype, effectively requiring diverse potato-farming environments, conditions and practices to be standardized in reflection of the 'sovereign' laboratory (Scott, 1998). While such optimization was scientifically justified in its own terms, those terms themselves demanded questioning. They also performed an epistemic culture of non-knowledge or ignorance, through their mutually correspondent epistemic and institutional framing.

ANT has illuminated how technological standardization works to universalize scientific knowledge, through laboratory practices that reshape the world via the circulation of commensurable objects (O'Connell, 1993). However, it fails to address the power asymmetries generated through these processes. STS work, by scholars like Star (1991), has shed important light on how technological standardization black-boxes heterogeneity and difference, and disables certain non-aligned forms of life, in reflection - and reinforcement of asymmetric power (see also Mackenzie et al., 2013). James C. Scott's extensive anthropological work also highlights the issue of power asymmetries and how these are obscured in natural knowledge-cultures. For example, drawing on Foucault, he shows how states and markets have organized societies and ecosystems so as to render them 'legible' (Scott, 1998), for purposes of control. As noted by Scott and Star, as well as Busch (2011), such strategies of extraction, simplification, standardization and legibility-making attempt deletion of objects, phenomena and forms of life that do not comply with centres of surveillance, calculation and power. In return, non-compliant actors may resist such standardization and legibility, through manifest resistance, or through cultivating autonomy through invisibility (Scott, 1990).

Critical STS resources - the analytic of epistemic cultures, complemented by the model of ignorance and exclusion as an effect of framing, co-production, the ANT account of immutable mobiles, and analyses of relevant power-knowledge asymmetries - provide a perspective from which to explore connections between the most technical and social aspects of nonknowledge in the Mexican GM maize controversy. In the following sections, we discuss how DNA detection methodologies enacted selective reduction and standardization of what are in situ fluid, as well as connected in-the-field genomes, so as to produce an in vitro knowledge of them, that may have co-produced a corresponding cognitive, political, commercial and cultural order (Jasanoff, 2004, 2006). Our aim in this case-history is to elucidate the multilayered ways in which scientific knowledge - including as a form of non-knowledge - can act in the name of nature to reflect and embody, and thus perform, particular cultural values and power relations. 


\section{Transgene escape: The trajectory of a research and policy problem}

In the 1970s, research had found that $20 \%$ of samples from local landraces of maize in Chiapas showed traits introgressed from Green Revolution hybrid varieties (Ortega Paczka, 1973). Two decades later, in 1990, the US geneticist John Doebley published the first molecular evidence for gene flow between maize and wild Zea relatives. He warned that 'an engineered gene in maize could spread ... throughout the teosinte population' that grow in some regions of Mexico, and proposed 'not to grow transgenic maize in those regions' (Doebley, 1990: 443). However, policymakers and mainstream science did not pick up this unwelcome early evidence of gene flow. In 1988, GM maize field trials were authorized nationwide in Mexico, when President Salinas de Gortari initiated negotiation of the North American Free Trade Agreement (NAFTA). Enacted in 1994, NAFTA led to an import boom of US maize in Mexico. US commercial cultivation of transgenic maize in Mexico started in 1995.

Before 2001, in both the US and Mexico, minimal attention was paid to agroecological implications of maize transgene flow as a research or policy issue. In the US, the issue was not addressed by the National Academy of Sciences' report on the impacts of GMOs (National Research Council, 2002), and none of the hundreds of biosafety research projects submitted to the Biotech Risk Assessment Program between 1992 and 2000 addressed it. ${ }^{1}$ In Mexico, the issue did emerge within the small group of experts on the Mexican National Agricultural Biosafety Committee (CNBA). Among these, the agronomist and biotechnologist Antonio Serratos co-organized two meetings to address transgene escape in 1995 and 1997 (Serratos et al., 1997, 2000). However, although a few papers on gene flow were published in the meeting proceedings, these did not find their way into international journals. And while a few members of the CNBA persuaded the Ministry of Agriculture to issue a de facto moratorium on Mexican GM corn field trials and commercial growing in 1998, pro-GM interests counterlobbied. These efforts included a letter to Science arguing that there was 'no need for concern' about gene-escape from transgenic maize (Martinez-Soriano et al., 2000).

The issue of maize transgene flow mushroomed dramatically in November 2001, when Quist and Chapela's Nature article reported 'the presence of introgressed transgenic DNA constructs in native maize landraces grown in 2000, in remote mountains in Oaxaca, Mexico' (Quist and Chapela, 2001: 541). One year after the UN Cartagena protocol on global biosafety, and three years after the Mexican moratorium on GM corn field trials, the discovery of transgenes in a remote southern area suggested a radical failure of Mexico's national biosafety policy, as well as the need for research 'to trace the flow of genetic material over bio-geographical regions' (p. 542).

However, these findings - and the challenge they posed to industry and government reassurances of control and containment - provoked immediate and intense contestation (Delborne, 2008: 2011). In April 2002, the editor of Nature took the unprecedented step of 
withdrawing the journal's support for the original article, stating that 'the evidence available is not sufficient to justify the publication of the original paper' (Nature, 2002: 600). Criticisms of Quist and Chapela's article actually focused on a point that was secondary to the central issue, the finding of transgenes in samples of indigenous landraces. The critics instead alleged that the study over-interpreted iPCR results that indicated fragmentation of transgene inserts. However, they also mostly succeeded in undermining the credibility of the central finding of transgenes in indigenous maize.

Nonetheless, especially in Mexico, the Nature article prompted a hot political struggle around GM crops, including research and policy activism and widespread anti-genetic engineering campaigns from peasant, indigenous and environmental organizations (Foyer, 2010; Kinchy, 2012). A Ministry of Environment agency, the Instituto Nacional de Ecologia (INE), and the Department of Agriculture sampled maize throughout Mexico and confirmed Quist and Chapela's findings (Ezcurra et. al., 2001; Alvarez, 2002). Much positive data was released by the authorities and by NGOs in international conferences and press releases. However, none of this was published in peer-reviewed scientific journals (CECCAM et al., 2003; Foyer, 2010) until 2007, and, as we describe below, the only intervening journal article was instead one (Ortiz-Garcia et al, 2005) that claimed to show no such GM contamination of indigenous maize fields.

In 2002, a group of organizations and rural communities petitioned the Commission for Environmental Cooperation (CEC), a body created under the NAFTA, to attend to a wider set of issues than environmental risk assessment alone, such as the cultural value of maize and peasants' livelihoods. In their report on maize and biodiversity, CEC experts echoed some of these dimensions, resulting in rejection of the experts' recommendations by the governments of the US and Canada. However, the CEC report still framed the issues mainly around risks and narrow technical questions. It affirmed the presence of transgenes in this way:

Transgenes have entered some landraces of maize in Mexico. This finding was confirmed by scientific studies sponsored by the Mexican government. However, no peer-reviewed summaries of this work have been published and information released to the public has been vague (CEC, 2004, 16).

While it acknowledged transgene escape, this framing of the issues required that data be published in peer-reviewed journals in order to be deemed trustworthy and relevant to policy. This requirement became a strategic resource for those corporate and policy actors who were concerned to cool the controversy and lift the ban on GM maize, until further reports of transgenes in Mexican maize were published in scientific journals in 2007.

In a second phase of the controversy, from 2004 to 2008, the pro-GM policy line of the Department of Agriculture won its battle against the more cautious Mexican government environmental authorities. The latter had achieved Mexico's ratification of the UN 2000 
Cartagena Protocol on Biosafety. However, the agricultural authorities retaliated with Mexico's 2003 signing of the North American Biotechnology Initiative, and a 2005 biosafety law that accommodated lifting the GM maize moratorium (Foyer, 2010). This policy shift was supported by a 2005 article in the prominent journal Proceedings of the US National Academy of Science (PNAS). The article, published via a fast-track procedure, reported no findings of transgenes in Oaxacan mountains from 2003 to 2004 (Ortiz-García et al., 2005). Negating the many positive results found and reported by public agencies and researchers, including in the year 2003 (CIBIOGEM, 2004; Landavazo Gamboa et. al., 2006), this one negative article was the most intensely publicized and globally recognized report on the topic. Until 2007, the positive studies could not get published in international scientific journals, despite submissions from 2002 onward - all rejected - to Nature, PNAS and others.

Curiously, Ortiz-Garcia, the lead author of the 2005 PNAS article, had been one of the coauthors of a manuscript that reported positive findings, which had then recently been rejected by Nature (interview with S. Ortiz-García, 2008). Her other co-authors of the PNAS article included the directors of INE, a senior scientist of the US GMO detection company Genetic ID, and US Ohio State University professor Alison Snow. The article was the main, indeed only, reference used to discredit Quist and Chapela over the issue of whether transgenes had ever really escaped into Mexican landraces. At the very least, the PNAS article suggested that transgenes had disappeared from the Oaxaca region. Reports of the PNAS article in Nature and Science with titles like, 'Four years on, no transgenes found in Mexican maize' and 'Calming fears, no foreign genes found in Mexican maize', exuded blanket scientific reassurance and invited extrapolation of the negative findings to all Mexican territory (Marris, 2005; Kaiser, 2005). In Mexico, this high-profile absence/reversibility narrative helped government and industry actors to claim that it is proven that the transgenes do not remain in the environment' (Biotech industry representative in Mexico, quoted by Fitting, 2011, 59; see also Prakash, 2005).

The publication, between 2007 and 2009, of three studies showing positive results in several states of Mexico opened a new phase of the controversy. The first, coordinated by former CNBA member Antonio Serratos and published in Frontiers in Ecology and the Environment, reported the presence of 'transgenic proteins in maize' in the Federal District (i.e., around Mexico City) (Serratos et al, 2007). A second article, authored by Piñeyro-Nelson et al. (2009), a research team from the Universidad Nacional Autónoma México (UNAM) in Mexico City, was published in Molecular Ecology. This study reported positive results (at overall frequencies of around 1\%) for samples collected in 2001 and 2004 in Oaxaca. These results confirmed Quist and Chapela's findings. A third article, co-authored by a group of US and Mexican scientists, was published in PLoS One (Dyer et al., 2009). The article reported findings of the GM protein in more than $3 \%$ of the 419 seed-lots sampled in 2002 across 14 Mexican states. 
These three positive sets of findings, however, attracted little attention in scientific and media arenas compared with Ortiz-García et al.'s 2005 article. Only Piñeyro-Nelson et al.'s findings were covered in another major publication, a 'news' section in Nature (Dalton, 2008). Neither did the findings influence the Mexican policy arena. This was striking, particularly in light of the 2009 public volte-face by one of the two US co-authors of the 2005 Ortiz-Garcia 'denial' findings (Snow, 2009). The author declared herself fully convinced by Piñeyro-Nelson et al.'s work. Given the structure of institutional power in Mexico, neither farmers, environmental and indigenous activist movements, nor independent scientists could use these unquestioned positive scientific findings to alter the pro-GM policy line that had solidified around 2005. Once political closure had been achieved, the new scientific findings seemed unable to reopen the debate over transgenes. GM maize field trials were officially authorized in 2009 (a decision suspended recently by judicial interventions).

An issue relevant to their lack of policy influence is that these three publications were in journals of lesser standing than Nature and PNAS. The world of scientific publications is highly hierarchical, and the importance of articles both within and beyond science itself is determined by their host journals' 'impact factors'. In 2009, Nature's impact factor was 34.48 and PNAS's was 9.43, while Frontiers in Ecology and the Environment, Molecular Ecology, and PLoS One's were between 4.35 and 6.92. Correspondingly, different detection methodologies had different epistemic authority. The Frontiers in Ecology and the Environment and PLoS One articles, which reported studies that used agronomic or immunological protein-assays rather than higher profile DNA-based methodologies, failed to attract weight. Piñeyro-Nelson et al.'s 2009 article did use DNA-based assays, but these were attacked by Genetic-ID scientists as misinterpretations of the PCR results or even 'indicative of contamination in the laboratory' (Schoel and Fagan, 2009: 4143). We return to this later.

Why was a single publication of negative findings enough to cool down the controversy by 2005, while several other simultaneous surveys that confirmed transgenic findings in Mexican landraces did not enjoy international scientific journal publication? Why, while most biologists acknowledge that maize gene-flow occurs at significant rates, was further positive DNA-based evidence repeatedly required? Why was DNA evidence deemed the only legitimate proof, while protein-detection from simple immunoassays was deemed illegitimate, despite having been accepted in the US StarLink case? The next section analyses how such a particular standard of evidence - whose influence on the overall trajectory of the controversy has been shown - became hegemonic, and how it also embodied and performed a much larger set of non-scientific commitments. 


\section{Making transgenes visible: Constructing the authority of in vitro knowledge}

We have tracked all the GM sampling surveys conducted in Mexico after Quist and Chapela's 2001 article, and documented their subsequent fates in scientific and public arenas. On the one hand, as Table 1 shows, out of more than 18 surveys, only one - that published in the high-profile international journal, PNAS (Ortiz-García et al., 2005) - reported not finding transgenes in landraces. On the other hand, of the more than 17 surveys that reported positive findings, only three achieved international journal publication. These three published articles are the survivors of obstacle course-like peer-review processes: Piñeyro-Nelson et al. (2009) was published only after rejected submissions to Nature in 2002, PNAS in 2007 and PLoS One in 2008; similarly Dyer et al. (2008) had been previously rejected by PNAS, Applied Ecology and Agriculture \& Human Values. This suggests that, after 2001, positive results faced more difficulties than negative results in attempts to achieve publication in authoritative journals. Nature and PNAS operated as gate-keepers, channelling and shaping what knowledge was ultimately produced and which kinds of evidence constitute reliable proof. In this section, we examine how these high profile journals both privileged a particular way of detecting transgene flow and also discarded others' understandings, thereby disempowering subaltern voices on more than gene-flow alone. 
Table 1. An overview of GM Maize sampling surveys in Mexico (2001-2009) and their fate

\begin{tabular}{|c|c|c|}
\hline $\begin{array}{l}\text { Surveys post Quist \& } \\
\text { Chapela (2001) }\end{array}$ & Detecting transgenes & Not detecting transgenes \\
\hline $\begin{array}{l}\text { Data published in a peer- } \\
\text { reviewed international } \\
\text { journal }\end{array}$ & \begin{tabular}{l}
\multicolumn{1}{c}{$\mathbf{3}$} \\
Serratos et al (2007) \\
Piñeyro-Nelson et al. (2009) \\
Dyer et al. (2009)
\end{tabular} & $\begin{array}{l}\text { Ortiz-Garcia et al. (2005), PNAS, fast } \\
\text { track }\end{array}$ \\
\hline $\begin{array}{l}\text { Data submitted in a } \\
\text { manuscript but rejected } \\
\text { by peer-reviewed } \\
\text { international journals }\end{array}$ & $\begin{array}{l}\text { 6+ } \\
\text { Alvarez-Buylla et al. to Nature, } \\
2002 \\
\text { Piñeyro-Nelson et al. to PNAS, } \\
2007 \\
\text { Piñeyro-Nelson et al. to PloS1, } \\
2008 \\
\text { Dyer et al. to PNAS (Mexico } \\
\text { Rural Household Survey } \\
\text { (ENHRUM), 2002) } \\
\text { Dyer et al. to Applied Ecology } \\
\text { (idem.) } \\
\text { Dyer et al. to Agriculture \& } \\
\text { Human Values (idem.) } \\
\end{array}$ & $\mathbf{0}$ \\
\hline $\begin{array}{l}\text { Data not submitted to any } \\
\text { international journal } \\
\text { (with year of collecting) }\end{array}$ & $\begin{array}{c}\text { 9+ } \\
\text { INE : 2001-2009 }(2003 \& 2004 \\
\text { excluded) } \\
\text { Grupo ad-hoc (Cibiogem- } \\
\text { Sagarpa): 2001, 2002 } \\
\text { INIFAP : 2003 (Landavazo } \\
\text { Gamboa et al., 2006) } \\
\text { ETC group-CECCAM-CASIFOP } \\
\text { (Press release in 2003) }\end{array}$ & - \\
\hline
\end{tabular}

N.B. When a same institution conducted a survey with several collecting years, we counted it as several different surveys.

How can invisible transgenes be turned into visible signals and meanings? We have observed four ways of making transgenes visible during the controversy: 1) phenotypic judgments derived from consideration of the whole plant; 2) the search for agronomic traits specifically expressed in the GM plants; 3 ) the search for distinct protein products of the transgenes in plant cells; and 4) the search for transgenic DNA-sequences in the plant genome.

The first approach was implemented by some indigenous community organizations, members of the Red en defensa del maís activist network. They claimed that shamans and some experienced farmers could visually detect 'contaminated' plants because they look monstrous 
(Interview with Aldo Gonzales, 2009). Monster hunting, resonating with cosmologies that associate monstrosities with a moral hurt, constituted a tool for raising community awareness against GMOs.

The second avenue tested the expression of agronomic traits specific to the GM plants. As most transgenic constructs confer tolerance to a specific herbicide, the finding of a landrace that is unaffected by application of a particular herbicide constitutes evidence of transgene introgression. This type of test was easy to conduct, in either an experimental plot or the field, by applying the herbicide to a leaf with a pencil. The zone would turn yellow if non-transgenic and remain green if transgenic.

The third option tested the expression of transgene protein products through immunological methods (Elisa tests, lateral flow, strip band, etc.). These techniques are cheap, reliable and simple. They were the most used methods in identity-preservation routines along the food chain by industry and regulatory agencies in the US until the mid-2000s. In 2000, Friends of the Earth sampled food products and engaged a then young detection company, Genetic ID, which ran immunological tests in taco shells, finding a protein (Cry9C) belonging to an unauthorized GM maize (StarLink) commercialized by Aventis for animal feed. Within a few days, Kraft Foods, having double-checked and confirmed this contamination, recalled 300 different product-lines. This caused large drops in US corn shipments and Aventis was forced to pay almost US $\$ 1$ billion to affected farmers, consumers and companies (Lezaun, 2003). So, immunological detection methods were compelling enough to authorize strong policy measures.

The fourth approach was based on the molecular identification of DNA sequences specific to the genetic construct transferred to the plant genome in the transformation event (e.g, the Southern Blots hybridization technique, and qualitative and quantitative Polymerase Chain Reaction (PCR) techniques). The crucial process of PCR amplification of DNA from samples is notoriously sensitive to variable factors (including contamination, but also genuine differences of genome complexity between hybrid and land-race maize genomes), especially when quantification (qPCR) is being attempted. PCR methods, though precise and technologically sophisticated, are hard to handle properly and prone to both false positives and false negatives. They also require knowledge of the precise DNA sequences of the GM constructs, which are often restricted from scientific access as commercially confidential.

During the controversy, these DNA methodologies became the gold standard of evidence, to the detriment of the three other ways of rendering transgenes visible. By late 2000, Quist and Chapela could have reported transgene findings based on rapid immunoassay methods, as was done in the StarLink case, or in the 1999 case in which Greenpeace Mexico reported detection of GM Bt maize on maize shipments from the US. But, to optimize the academic and policy impact of their discovery, Quist and Chapela preferred to wait and carefully construct 
both their PCR methodology and their audience (Delborne, 2011). Their report, however, was criticized for using only PCR methods, which were deemed prone to false positives (Kaplinsky et al., 2002; Christou, 2002). Quist and Chapela, therefore, conducted DNA hybridization (i.e., Southern blot) tests to confirm their findings (Quist and Chapela, 2002: 602). This episode set the standard: when new manuscripts were submitted to Nature to provide evidence for the presence of transgenes in Mexican landraces, they had to use both PCR and Southern blot to have a chance of acceptance. While phenotypic, agronomic or immunological evidence was regarded as sufficient in other cases (e.g., the StarLink case), Nature and PNAS only published articles based on DNA methods. This hegemony of DNA-based hard evidence had deep political impacts in the Mexican controversy.

Unsurprisingly, indigenous groups' claims to ascertain 'contaminated' maize plants visually (as monsters) had no authority in the international scientific arena, nor in the national policy arena. Most maize scientists consider the existence of monstrous forms in maize a well-known and longstanding phenomenon. Furthermore, the DNA-based gold standard of evidence embodied the idea that the laboratory, not the field, was the legitimate place to produce knowledge. This meant that, a priori, community organizations could not produce legitimate data. For instance, the regional indigenous organization in Oaxaca where Quist had first detected transgenes in 2000, UZACHI, wanted to conduct detection and monitoring itself. It had a fairly well equipped laboratory and its director had learned molecular techniques. But the Instituto Nacional de Ecologia (INE) refused to defer to UZACHI for the testing of the samples collected in UZACHI communities (interview with L. Perez, 2009). Seeking hard evidence with international credibility in mind, INE preferred to subcontract public and private biotechnology laboratories for the analytical work (interview with S. Ortiz-García, 2008). A coalition of NGOs and community organizations decided to use immunological tests to conduct their own survey, independent from the government. They reported the presence of transgenes in landraces in several Mexican states (CECCAM et al., 2003). This community science strategy aimed both at producing evidence more rapidly than studies stuck in long peer-review processes, and at 'empowering local farming communities' (interview with Ana de Ita, 2009). But these NGO findings and their subsequent 'open letter' to the government failed to influence policy or to reach the international press. Even the fact that they found Cry9C, the allergen protein present in StarLink, in many samples did not make a difference. A Mexican scientist noted that 'the problem in Mexico ... is that nobody cares about what is not published in an international journal', while reflecting on the strong policy gate-keeping influence of academic journals (Interview with Francisca Acevedo, 2008). Government officials dismissed these results as anecdotal and unreliable because they were not published in a peer-reviewed journal.

Not only farmers' and indigenous organizations' knowledge and claims were disempowered by the DNA-based proof requirement enforced by top scientific journals. Mexican agronomists' in situ expertise was also discarded. Heirs of a research school initiated by 15 
Hernández Xolocotzi (1913-1991) who had surveyed maize landraces with Green Revolution scientists in the 1950s, maize genetic resource specialists possess an in-depth knowledge of maize landraces, at the crossroads of botanical, genetic, agronomic and ethnoecological perspectives. These maize scientists (calling themselves 'maiceros') can morphologically identify any maize plant as one of the approximately 60 races identified in Mexico. They can also phenotypically distinguish any modern commercial hybrid from local landraces, or from intermediary forms. This expertise provides evidence about whether a plant that turned positive in a detection test is a GMO commercial hybrid (i.e., for some reason 'lost' in a farmer's field) or a landrace that has introgressed a transgene into its own genome. But this phenotypic expertise was rejected by the molecular biologists who served as reviewers for the top scientific journals (Referee 1 on Alvarez-Buylla et al.'s rejected manuscript, Nature to Dr. Ezcurra, Sept. 22, 2002, personal communication from S. Ortiz-Garcia). Maiceros' knowledge was deemed inadequate.

The requirement for DNA-based methodologies as the gold standard of evidence not only marginalized farmers and Mexican maize scientists, but also made it harder for Mexican molecular biologists to contribute effectively to the debate. In the early 2000s, these DNAbased techniques were indeed mastered only by a few Mexican laboratories, for research rather than for routine testing. However, it proved hard for these laboratories to meet the standards imposed by high-profile journals. This is why two of the three 2007-2009 publications that reported positive findings (Serratos et al., 2007; Dyer et al., 2009) relied only on immunoassays. A third Mexican group - composed of Elena Alvarez-Buylla's unit at UNAM, Rafael Rivera's group at Cinvestav, and scientists from the INE - worked hard in 2002 to meet Nature's standards of proof, saying: 'We had to repeat PCR assays in large numbers.... Develop a satisfying Southern blot methodology took us a hard work.... We met many kinds of hurdles' (Interview with Elena Alvarez-Buylla, 2008). Finally, the manuscript that reported positive results was rejected by Nature, for lack of 'standard procedure and controls' for PCR and Southern Blot (Referee 2 comment, in Nature to E. Ezcurra September 23, 2002, personal communication from E. Alvarez-Buylla).

It was exactly this obstacle of producing publishable data that led to a split within the group. After Nature's refusal, INE sent their samples to the US-based Genetic ID (GID). From these, GID obtained inconsistent and 'strange' (interview with S. Ortiz-García, 2008) quantitative PCR results and, rather than consider the possibility that the genomic heterogeneity and complexity of Mexican landraces (see below) could explain such results, concluded that 'contamination' had occurred in the two Mexican labs. Persuaded by GID, INE, which had no expertise in molecular methods, stopped delegating the analytical work to Alvarez-Buylla and Rivera's laboratories and began collaboration with GID instead. This resulted in the switch to the negative 2005 PNAS publication (Interviews with Ortiz-García, Alvarez-Buylla and Piñeyro-Nelson, 2009). Having to provide both DNA-based and immunological evidence, the two public Mexican laboratories took some further years to verify and publish their positive 16 
data (Piñeyro-Nelson et al., 2009) - which also by then included a direct 'blind' test of GID's own claims to exclusive methodological purity.

Thus, in the 2000s, the growing authority of DNA-based detection techniques, and the corresponding stringent norms of proof of leading scientific journals, proved instrumental in silencing other voices and their forms of maize expertise. This growing authority was fuelled by rapid advances in molecular biotechnologies (viz., new generations of PCR techniques) and, strengthened by the view of DNA as the universal basic molecule of life, the demand that DNA technologies be the most precise and accurate (Rabinow, 1996; Fox-Keller, 2000).

\section{The long march of a bio-cultural understanding of gene flow}

Spearheaded in Mexico after World War Two by the International Maize and Wheat Improvement Centre (CIMMYT), the Green Revolution paradigm included: a division of labor between breeders as innovators and farmers as mere users; a strong analytical separation between the genotype and the environment; and a standardization of the latter around the laboratory-manipulated 'optimal' genotype (van der Ploeg, 1993). This genetic agricultural modernization project succeeded in increasing production in the large farms of the northern states. Nevertheless, it failed to meet the needs of most Mexican farmers, since indigenous maize landraces rather than modern hybrids are still grown on an estimated $80 \%$ of maize acreage (Aquino et al., 2001).

By 1970, some Mexican agricultural scientists had already reported that farmers could not afford Green Revolution technological packages, and that hybrids were not adapted to farmers' environments (Cotter, 2003: 290-309). Led by Hernández Xolocotzi, these scientists pioneered agroecological approaches - which combined ethnobotany, agronomy, genetics and ecology - and called for a re-Mexicanization of research (Hernández Xolocotzi, 1977). Although initially marginalized, this agroecological and ethnoecological research school was developed again in the mid-1990s by the UC Davis anthropologist Steve Brush, via a new worldwide program to implement participatory management of crop diversity (Brush, 2000; Bonneuil and Fenzi, 2011).

The new program funded in situ maize diversity conservation projects in Mexico and fuelled new research on farmers' seed systems. This bio-cultural approach provided a deeper understanding of the farmers' very diverse knowledge-practices - cosmologies, seed sharing, mixing of seed, farmer selection, cultural transmission of practical farming savvy, cooking knowledge and complex multiple-use criteria in continual play. Farmers' practices had been operating as a distributed evolutionary process acting on the genetic structure and dynamics of maize populations at a landscape level, over decades and centuries in a wide range of ecological conditions. The farmers' system, which manages and selects from numerous 'meta- 
populations' in a wide range of environments, account both for the existence of some genetic continuity and for the maintenance of diversity among numerous maize landraces; the system also maintains some stability at the phenotypic level (Bellon, 1996; Pressoir and Berthaud, 2004; Perales et al., 2003).

However, anti-reductionist and field-sensitive approaches remained marginal. As a population geneticist at CYMMIT put it, "The then head of the CIMMYT viewed us as "tree huggers"... We preached in the desert' (interview with J. Berthaud, 2009). Molecular biology and its promised molecular intensification of the Green Revolution paradigm, on the one hand, and bio-cultural approaches to gene-flow, on the other, constituted two different epistemic cultures. Each developed in integration with a different seed system, as outlined in Figure 1: a top-down industrialized maize-world, in one case, and a web-like bio-cultural indigenous maize seed-system, in the other. The two cultures differ deeply in their views of what genes can do, how genes flow and what maize diversity is.

The molecular biology epistemic culture gives preference to static and homogeneous forms of life - which are deemed better for generating robust commercial technoscience - reliable mass-production, global markets and intellectual property (Bonneuil, 2014). It views crop diversity as a standing reserve, which local farmers hardly know how to harness, and sets a modernist boundary between 'nature' and 'culture'. Crop biodiversity is abstracted from its ecological and social contexts, to be used as a resource for crafting elite commodity-cultivars (Bonneuil and Fenzi, 2011). These abstracted 'genetic resources' are centralized in ex-situ seed-banks and processed through molecular control laboratories, which constitute the centres of calculation of a tree-like seed system. Co-produced with industrial monocropping of commercial hybrids for global markets (see Figure 1a), the molecular biology epistemic culture tends to see diversity, genome-variation and in situ gene-flow only as problems to be controlled. 


\section{Figure 1. Contrasting seed systems, contrasting epistemic cultures}

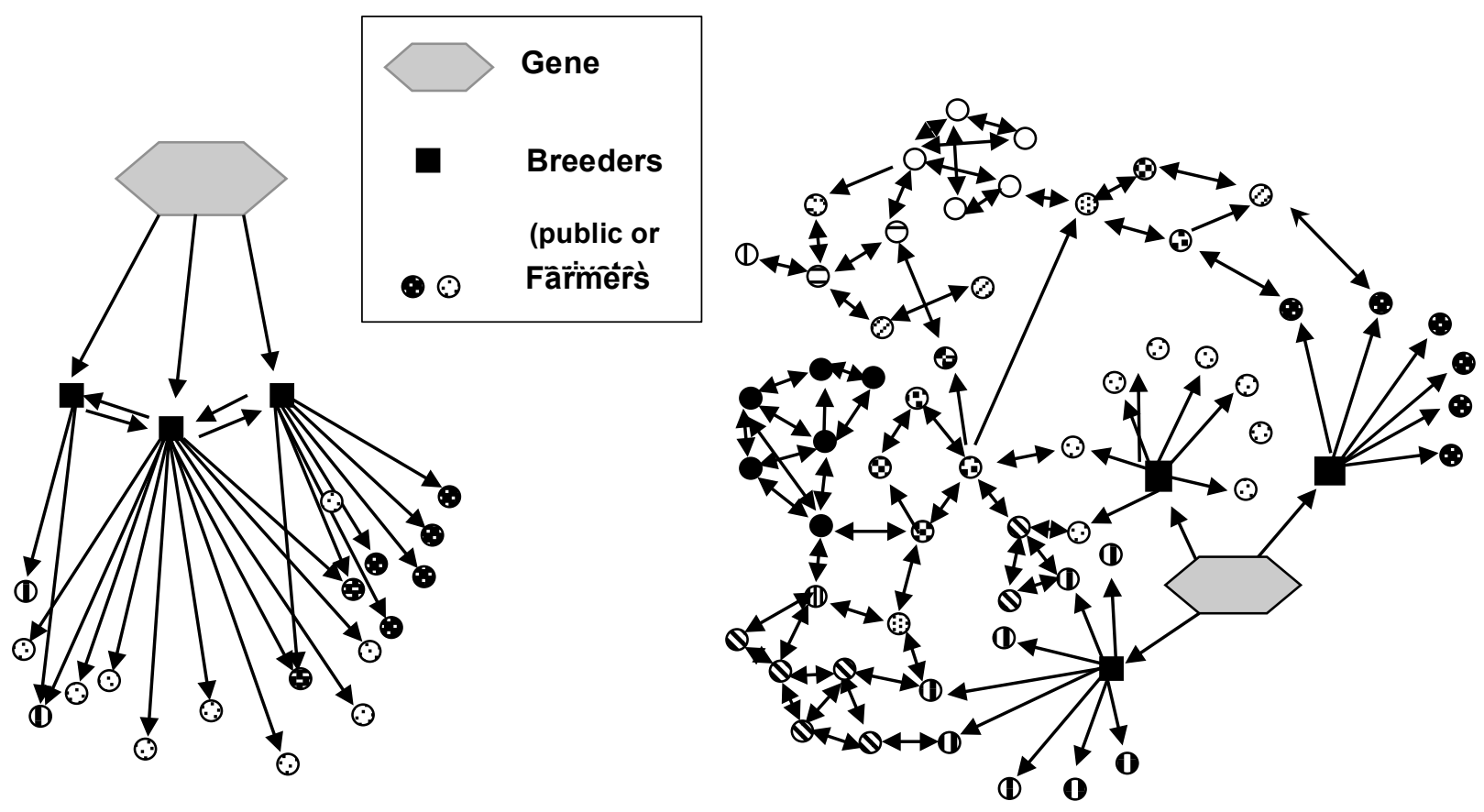

\section{1.a. - Green revolution seed system}

\section{1.b. Farmers' web-like seed system}

Fig. 1.a and 1.b. illustrate two kinds of seed system, each having its associated gene flow pattern and its knowledge culture:

\section{1. a. Top-down seed system}

A "formal" (industrial) seed system is typical of the genetic modernism of 20th century Green Revolutions both in the industrialiazed and developing countries (Bonneuil, 2014).

Farmers are mere users. They don't exchange seed and buy new commercial seed every year.

The architecture of this seed system is tree-like, fordist. It displays a top-down command and control model, that is similar to the DNA-> RNA-> Protein information flow in the 'central dogma' of molecular biology (Fox-Keller, 2000)

Crop genetic diversity, is stored as 'genetic resources' in gene banks. It evolves only in breeders's plots, not in situ at landscape level. Effective gene flow occurs only in breeding, not in the field (in seed production plots, distance and technical norms ensure a certain level of seed purity). Only a few well-defined homogeneous cultivars F1 hybrid cultivars) are allowed in the landscape (hence, only 3 cultivars are represented on fig. a).

\section{1. b. Web-like seed system}

Besides the formal seed system (lower right), and partly connected to it, evolves a farmers' (population varieties) "informal" seed system (upper left).

Farmers save seeds, select preferred types and exchange genes (via seed gift or sale or cross-pollination across fields) The architecture of this seed is web-like: a distributed network of interconnected populations, that is similar to 'metapopulation models' of evolutionary/conservation biology. Such heterogeneous and web-like structures are less amenable to central control (Scott, 1998) Genetic diversity in such a seed system depends on the array of environmental conditions operating various selection pressures on plants, on the level of connectivity between maize populations (which depends on biological parameters and human exchanges) and on farmers practices (selection, preferences, etc.). A high (and evolving) level of genetic diversity is maintained in agricultural landscapes (hence, 3 green revolution cultivars + a dozen more population varieties are represented on fig. 1.b. 
In contrast, the bio-cultural epistemic culture views maize diversity as a web of dynamic ecological and human connections, 'not just as "genetic resource", but as diversity in the field' (interview with M Bellon, April 30, 2009). Rather than basing sound science on purified systems amenable to property rights, the bio-cultural approach views environmental and genetic heterogeneity, web-like in situ gene-flows (see Figure 1b) and autonomous diverse traffic across the nature/culture border as its very object of investigation (Bellon, 1996; Brush, 2000; Dyer and Taylor, 2008; van Herwaarden et al., 2012).

\section{Making farmers invisible}

The tension between molecular biological and bio-cultural understandings of gene flow was far more than epistemic. Strikingly, farmers' roles in shaping gene flows at landscape levels were erased from the two articles published in the higher standing journals. Within the constraints of a short letter to Nature, Quist and Chapela (University of California, Berkeley researchers) were led to obscure their long-standing collaboration with Oaxacan indigenous communities, and to elide the agency of farmers in the shaping of maize genetic landscapes (Quist and Chapela, 2001; interview with Chapela, November 2, 2006). This spiriting away of farmers to meet Nature's narrative genre repeats the $17^{\text {th }}$ century scientific revolution's 'invisible technician' accounts (Shapin, 1989). In the PNAS article (Ortiz-Garcia et al., 2005), there are twenty-one references to 'farmers', but farmers are always treated as mere receptors of scientific knowledge. Indigenous farmers, who may have 'unknowingly' planted GM grain, are depicted as an epistemically vacuous public with its own (non-scientific, 'local' and 'traditional') 'cultural perceptions' and irrational fears of GMOs. Hence there was need for a patronizing scientific expertise (Wynne, 1996) for the state to inform and reassure those 'traditional farmers' (Ortiz-García et al., 2005). Only the lower ranking later articles acknowledged farmers' agency in the dynamic shaping of maize genetic diversity at landscape levels, and reported having interviewed dozens of farmers to derive knowledge of the 'seed systems' that crucially informed their sampling or modeling strategies (Serratos et al., 2007; Piñeyro and al. 2009a; Dyer et al, 2009). The lower ranking articles reflected an alternative, bio-cultural, way of making scientific knowledge, one rejected by Nature and PNAS.

Such high-profile journals also contributed to the production of ignorance about the human dimensions of (trans)gene flow via the letters that they selected (and rejected) for publication after Quist and Chapela's article. Although Nature only published technical molecular biology critiques, we found additional submitted comments from the bio-cultural perspective that were rejected by Nature (Bellon and Berthaud, 2004; Soleri, personal communication). In these discarded comments, gene flow was not discussed as a surprise to be proven with hard 
molecular data, but as an already well-known reality, which might be key to maize diversity, depending on both biological parameters and farmers' practices.

Although marginalized by the molecular biology epistemic culture, the interdisciplinary (agronomic, anthropological, genetic and ecological) study of farmers' seed systems turned out to be essential knowledge. Because they collected maize in farming communities on a regular basis, the bio-cultural epistemic community practictioners were better prepared to design robust sampling schemes than were laboratory-based molecular biologists. In light of farmers' practices and maize pollination biology, bio-cultural practitioners knew that ears from the same plot and from the same household are closely genetically related, and on this basis noted a key limitation of Ortiz-García et al.'s 2005 PNAS article. Molecular biologists took the seeds deriving from a single cob as the unit of analysis. As a result, Ortiz-García et al. calculated that the probability of transgene presence in Oaxaca mountains was below $0.01 \%$. However, more robust sampling schemes determined the 'effective population size' - a population genetics concept, alien to molecular biology's epistemic culture - by taking the farm-household as the unit of analysis. This more refined bioculturally informed sampling and probabilistic analysis, based on population genetics and statistical and anthropological knowledge of farmers' seed systems, corrected this assessment to 1-4\% (using a sampling scheme encompassed only 124 different households), even before their differences in interpretation of PCR and gel-band readings (Cleveland et al. 2005).

It is astonishing that such a crucial issue as sampling did not enter the controversy before 2005, and it only did so through journals of lesser standing than Nature, Science and PNAS. This reflects the fact that peer-reviewers mobilized by high-profile journals were molecular biologists, who had poor knowledge and little interest in farmers' practices, population genetics and statistics. Typical here is the comment made by a reviewer for Nature in 2002:

If such gene flow is as frequent as is claimed by the authors ... it is necessary that the experimentation and analysis is absolutely watertight (...) My advice to the authors in the first instance is that they focus on fewer plants than in the present study and carry out the DNA and other analyses in much more detail than at present. (Nature Reviewer 1 of Alvarez-Buylla et al., 2002)

Such understanding of what constitutes a 'watertight' proof illustrates molecular biology's particular approach to making sense of and ordering the world: not using large data sets from carefully sampled materials in statistical analyses, nor modelling ecological or social complexity, but rather using sophisticated laboratory DNA tools to track, isolate and follow one (or a few) completely abstracted genes or gene-products at a time, in controlled environments, while working with artificially standardized living forms (Knorr-Cetina, 1999; Bonneuil 2006). While the epistemic objects of anthropologically informed population geneticists are genes as collectively circulating entities in socio-agro-ecosystems across large 
time and space ranges, molecular biology's epistemic objects are genes as manipulable entities in an experimental system nested in the controlled laboratory microworlds. The production of robust knowledge in molecular biology's epistemic culture thus requires that genes be abstracted/extracted from their cultural/ecological entanglements.

The extraction/purification approach of the epistemic culture of molecular biology produces ignorance (non-knowledge) simultaneously with knowledge. Moreover, ignorance coincides with and co-produces a denial of the value or relevance of indigenous maize culture, including its human and non-human participants. This example illustrates Proctor's model of ignorancemaking through framing - the active erasure of phenomena treated as out of scope, or as disorderly noise threatening the cognitive order and security of the dominant epistemic culture (Proctor, 2008). This entrenched epistemic culture transforms gene-flow from a complex, fluid and distributed bio-cultural process, that can be acted upon and spoken for by a variety of actors, into a laboratory object that only some particular scientists can speak for, in selected authoritative journals. It reduces socio-natures to what biotechnology (and its molecular-commercial culture) can see, to follow Scott's (1998) analysis. We return to this visibility question in the conclusions.

\section{Making genomes legible: Imperial molecular metrologies}

The reductionist erasure of the cultural and ecological dimensions of maize genetic landscapes - together with corresponding types of identity and power distribution - cannot deliver its promise to produce the type of knowledge considered most relevant without an additional implicit selective commitment. This particular assumption, of the homogeneity of maize landraces, in the image of commercial hybrid maize seeds, becomes normalized, and performed in practice as if natural. The norm enacted is that only a few genetically homogeneous, standard and tractable maize varieties ought to be used as research or calibration objects, even if a wide variety of genetically heterogeneous and complex varieties constitute Mexico's actual maize-genomic landscape. This section analyses this standardizing molecular metrology, which carries with it a politics that values homogeneity - a product of the co-evolution of industrial agriculture and modern genetics (Bonneuil, 2014) - and which is epistemically and politically blind to the heterogeneity of the bio-cultural world of Mexican landraces.

\section{Legible varieties}

When Quist and Chapela sent their first manuscript to Nature, one of the reviewers was not 'convinced that this work is strong enough for Nature' (Referee 2, May 2001, personal 
communication from Quist) and questioned its methodology, especially the choice of a negative control as yardstick for comparison with positive samples:

My main problem with the science is in the choice of control. Surely the appropriate control would be samples of seed from the native plant that were stored before GM maize was grown in Mexico (Referee 2, May 2001, personal communication from Quist).

This requirement assumed that before the putative arrival of transgenes in Oaxaca communities, there was one 'native plant,' which could act as the control - a single cultivar, or genotype, homogeneously spread in the whole area. Familiar with the sheer diversity of Oaxacan maize culture, the authors replied that

It is difficult, however, to know what [the referee] suggests by 'native plant'... The level of genetic heterogeneity in maize landraces... make such resolve equivocal at best, and usually impossible (Quist and Chapela to Nature, May 14, 2001, personal communication).

Regretting that 'the authors have made no attempts to address my fundamental criticism [concerning] the appropriate control,' the referee advised rejection of the revised manuscript: 'I just don't think the paper is anywhere near interesting or careful enough to merit publication' (Nature to Quist, 14 July, 2001, personal communication from Quist)

Derived from the comparison of near isogenic lines - a standard norm of proof among plant biotechnologists - this requirement from the reviewer implies the existence of a single homogeneous cultivar as a necessary control. In this particular epistemic culture, the production of exact knowledge implies ontological closure around a single 'native plant' that can stand for the 'before.' This unrealistic lab-molecular imaginary has its roots in $20^{\text {th }}$ century's genetic modernism (Bonneuil, 2014; Fox-Keller, 2000), which valued genetically uniform life forms (e.g., clones, pure lines, and F1 hybrids) and conceptualized biodiversity as stocks of genes rather than as ongoing flows (cf. the static notion of 'genetic resources'). As a result, the possibility of ambiguous intermediary forms or surreptitious circulations between the 'modern' and the 'traditional' is discarded.

The reviewer's methodological requirement reflects an apparently unwitting normalization of industrialized and genetically homogenous agricultural crops. The assumption of homogeneity is performed, not tested. It is imposed on Mexican landscapes and cultures, and on competing knowledge systems that are more respectful of those cultures' non-compliant complexities. This reflects an imaginary of a legible order of selective homogeneous genomes, one that had become the dominant material reality of agricultural research stations, biotech labs, industrial agriculture and Green Revolution landscapes. This high modernist way of constituting cultivars and their genomes also reflected a political project to discipline 
agriculturally and biologically diverse cultures and to govern rural societies. It is much harder for a state or for a global seed company to govern an informal, distributed, heterogeneously complex bio-social seed nexus than it is to govern a formal, streamlined, standardized, literally reduced - in terms of genetic, agronomic and cultural complexity - top-down system. Our analysis of molecular biology's modernist standardizing gaze extends Scott's (1998) concept of legibility. Scott showed that in order to 'improve' and maintain control over rural social-environmental complexes, modernist states, agribusiness companies and their scientific agents had to render them legible, homogenized so as to become commensurable with a centralized mode of knowing and an industrial mode of production. As we demonstrate next, this control strategy has deep molecular epistemic dimensions.

\section{Calibrating genomes}

Together with the 'choice' of controls, the issue of calibration of PCR detection assays played a key role in the controversy, while also embodying far-reaching cultural assumptions, material conditions and power relations. Genetic ID (GID) was founded by US molecular biologists in 1996. It soon became the world's biggest commercial GMO testing company. From 2001, GID led a campaign against immunological tests, which was launched with a study that undermined strip tests commercialized by a competitor (Fagan et al., 2001). Although this work was much criticized, once again for lack of an appropriate sampling method (Lezaun, 2003), GID succeeded in imposing PCR as the method of choice. GID promoted quantitative (q)PCR, or RealTime (rt)PCR (developed in 1999) as the best ways to detect GMOs. rtPCR is run in a closed system, less prone to contamination, and hence potentially less prone to false positives. Another advantage for commercial development is rtPCR's amenability to automation and routinized technician labor. But it also has some limits: to get proper data and to avoid false negatives it requires demanding preliminary calibration work (viz., choice of primer, reference gene, etc.) and hence relies upon particular assumptions about homogeneity and regularity of seed sample DNA. To allow quantification, it also has to make assumptions about DNA amplification rates with different materials and conditions.

In 2002, after Nature rejected the manuscript that confirmed Quist and Chapela's findings and reported many positives in two states of Mexico, one of the junior co-authors, Sol Ortiz-García from INE, sent samples to GID. As mentioned above, GID's report emphasized many inconsistencies in the results, obtained with qualitative and quantitative PCR (GID Report, Dec. 2002, personal communication by S. Ortiz-García). While discreetly working hard inhouse to tame these inconsistencies though further calibration and optimization of their rtPCR technique, rather than asking about what possible biological unknowns might have generated them (affirming Knorr-Cetina's (1999: 110) account of molecular biology epistemic culture's habit of 'semi-blind variation'), GID scientists told Ortiz-García that these strange 
results could only come from contamination in the public research laboratories that had prepared the samples (i.e., UNAM and Cinvestav's laboratories). Ortiz-García and INE officials gradually became convinced that only GID would provide reliable data for publication. They therefore adopted GID's assumption that Mexican maize genomes should behave as those to which GID was accustomed - typically big, homogenous, easily-sampled commercial shipments of modern hybrid seeds - akin to those assumed by the Nature referee dismissing Quist and Chapela, described in the preceding section . INE stopped collaboration with UNAM and Cinvestav, thus dropping Ortiz-Garcia's co-authorship of the positive transgene findings manuscript. Unannounced to those colleagues, the Ortiz-Garcia INE group instead worked with GID to prepare the 2005 PNAS publication, which, on the basis of GID's PCR analysis, reported no transgenes in all samples collected in Oaxaca in 2003 and 2004. This publication omitted mention of the many surveys that reported positives in several Mexican states in 2001, 2002 and 2003 samplings, including INE surveys. All these positives were retrospectively recast as false positives, in light of the apparent DNA contamination in public laboratories not specialized in the business of molecular detection. This was even though some of those positive findings resulted from non-DNA methods! The year following the publication of the PNAS article, in 2006, the Mexican Government bought the license for GID's proprietary testing technology, which is now used throughout the world by its Global Laboratory Alliance $\AA$ members, including a dozen governments. So the issue of which kind of methodology is relevant for producing evidence in detection controversies is not only about the sensitivity, stability or robustness of particular tools, but, ultimately, about who gets the business to monitor the global circulation of standardized commodities.

Piñeyro-Nelson et al.'s (2009) publication, authored by, among others, scientists from the two laboratories that GID accused of 'contamination' a few years earlier, challenged the kind of legibility at work in GID's detection methodologies. In particular they underlined that the molecular culture's blindness to research objects other than globally traded modern hybrid genomes exposed GID’s PCR methodology (and hence Ortiz-Garcia et al.'s 2005 PNAS article) as prone to false negatives:

while Genetic ID's method may be well suited for commercial use on commercial crop varieties in the U.S., they ... [are] working with the limited genetics of commercial hybrid maize... built upon a very homogeneous genetic background, a cross of Northern Flint x Southern Dent. Both inbreds ... are quite different from Mexican maize landraces (Piñeyro-Nelson et al., 2009b: 4146).

At stake here is the tension between current commercial quantitative PCR technologies and maize diversity. Maize genomics research has shown that Mexican maize landrace genomes are about $10 \%$ bigger and more variable in DNA sequence terms than laboratory pure lines and commercial hybrids, and they show a surprisingly limited level of colinearity with US cultivars. 'Colinearity' refers to the way genes are ordered along the chromosomes (Walbot, 
2008). Due to more active transposons, gypsies and mutational locus-variability, this higher genetic heterogeneity and fluidity in maize landraces points to many plausible inhibitionmechanisms of PCR amplification by various compounds present in landraces (e.g., secondary metabolites, oils, polysaccharides, etc.). These compounds need to be understood and controlled, at least analytically, if not practically, for their variable effects, rather than discarded as 'strange', as 'false positives', or as (incompetent) 'contamination'.

Still a contentious issue in 2001, when Quist and Chapela suggested it, it is now established that GM crop genomes undergo uncontrolled post-release 'event-specific variations' - changes in the location and sequence of the transferred sequence and its flanking sequences themselves (e.g., recombination, mutation, rearrangements due to transposons, etc.) (Matsuoka, 2002). For instance, Piñeyro-Nelson et al. (2009b) reported a case in which GID produced a false negative finding, by failing to detect transgenes in a well-known NK603 cultivar, which they had submitted to GID as a 'blind' test. This could be attributed to inefficient primer binding, due to post-release, event-specific variation in that cultivar ( $p$. 4148). In qPCR, the amplification of the target sequence (a sub-sequence of the transgenic construct) is compared to the amplification of a control sequence, or 'reference gene', which is assumed to behave similarly in all maize genomes. Commercial rtPCR utilizes only one or a few reference gene(s), such as the zein gene. But variability in these control sequences has been reported, and these differences lead to differential amplification. This messiness related to internal-standard variability may produce the kind of inconsistent results that are then scored negative in commercial testing methodologies, thus leaving additional room for false negatives (Piñeyro-Nelson et al., 2009b: Figure 1).

In summary, current DNA-based transgene detection methodologies, which are sold and defined as the gold-standard worldwide, carry an implicit assumption of universality and homogeneity of maize genomes, as if modern industrial agriculture hybrid maize were the universal norm. This is simply incompatible with Mexican maize genomic complexity and diversity. In this way, hard DNA-based proofs and commercial PCR methodologies enact a cultural domination of the world of industrial hybrids over the bio-cultural world of indigenous maize. But maize genomes are not made of discrete bounded genes, with similar sequences that sit in an orderly manner like beads on the DNA strand. Typical of Latour's recalcitrant objects, they resist such metrological alignment by the biomolecular genetic reductionism that co-evolved with commercial global industrial monocrop agriculture. These remaining bio-social recalcitrants, ambiguities and variability, which exist at the periphery of contemporary bio-empire (Jasanoff, 2006), suggest a path to alternative modernities - made of what could be reclaimed as 'other' biocultural entanglements, knowledge and identities (Foyer, 2010). 


\section{Conclusions}

We can now address the question raised in the introduction. Why did it take a decade to ascertain that transgenes have escaped from US GM corn industrial hybrids into local maize landraces, in a global centre of maize diversity? First, in Mexico and worldwide, many scientific and policy actors were happy to delegate to high-profile scientific journals the function of gate-keeping what was to be defined as scientifically sound, and hence policy relevant and authoritative, among the wide range of detection data, assumptions and claims advanced by a diversity of actors and knowledge cultures. Requiring peer-reviewed DNA and PCR-based proof proved a politically powerful way to contain the larger controversy sparked in 2001 into an esoteric, controlled and apparently purely technical question of scientific methodology.

In the elite arenas and journals that were given authority to channel and arbitrate the controversy, only one out of four knowledge-practices (viz., PCR) was considered reliable to make transgenes visible. This exclusion of other forms of expertise marginalized the voices of related social groups, including not only indigenous and socio-environmental organizations, but also disciplinary agronomists, population biologists and anthropologists who had joined to investigate the entangled biological and cultural processes that produce or harm crop genetic diversity. As such, the controversy over Mexican GM maize appears as a classic instance of imperialist subjection of subaltern knowledge-cultures, through the restrictive discourse of 'science' in general, and the monopoly form of molecular biology DNA-detection in particular.

Rural communities, and the scientists who took them seriously, were not given a voice in high-profile scientific institutions and journals or in policy circles. Instead, the framings and norms of proof of only one particular epistemic culture, molecular biology, were made to stand hegemonically for sound science. Moreover, in the later exchanges of this controversy, a particular, globally influential, molecular biology perspective, seen clearly in GID's attacks on opposing analyses, incorporated normative assumptions. Alternative approaches recognized other significantly different 'normalities', such as factors highly relevant for Mexican maize agriculture, but also implied different normative standards for molecular biological practices. PCR-based molecular biology has a blindness to sampling issues, to the dynamic, bio-cultural and extensive web-like functioning of genetic landscapes, and to the fluidity and diversity of maize genomes. Thus a singular reliance on PCR-based approaches failed to order the messiness of Mexican maize gene landscapes into unequivocally robust tests. Yet, at the same time, this hegemonic culture - which linked laboratory norms to journal and peer-review normative standards, and to media and political networks - erased from recognition and visibility some non-compliant forms of life and knowledge that may have helped understand gene flows, in all their exuberantly emergent, lively biosocial complexity. 
As the inventor of PCR himself noted, 'the remarkable part is that you will pull out a little piece of DNA from its context' (Mullis quoted in Rabinow, 1996: 6). The narrowing of the understanding of gene flow in Mexican agricultural landscapes and in the GM debate to a focus on ascertaining the presence/absence of transgenes as 'matter out of place' reduced the scientific and policy gaze around a particular vision of the gene and of the world. It imposed a view of cultivars and (trans)genes as self-sufficient, non-relational, stable and standardized units, as if their mode of existence and impact could be abstracted from their ecological and social bonds. Such a framing embodies and reinforces a cultural domination by the standardized(first) world of industrial maize - with its standardized genomes enabling patent-claims, commodity-circulation and centralized governing - over the complex, heterogeneous and web-like bio-cultural world of indigenous landraces and their peoples (see Figure 1).

The controversy over the detection of transgenes in Mexican maize landraces is not merely technical or even sociotechnical. This case is a political and cultural struggle, a new episode of a contentious cultural encounter between worldviews, values, forms of knowledge and forms of life that started with the Green Revolution. The molecular techniques and norms of proof that we have followed in Mexico, and from there around the globe, are key instruments in this cultural confrontation. As Sheila Jasanoff (2006) has shown, biotechnology holds much of its imperial power from particular metrologies, at work in risk assessment framings, standards and guidelines, databases, gene-banks, patent offices, detection methods, etc. These metrologies include: i) an ontological dimension, seen in the 'genetic resources' modernist paradigm and the denial of the bio-cultural nature and existence of gene-flow; ii) an epistemic dimension, seen in a hegemonic domination of molecular biology's epistemic culture over a bio-cultural epistemic culture; iii) a socio-ecological dimension, such as the need to partially align the conditions of the real world and the prevailing epistemic culture, so that the products from the biotech firms and detection labs may be said to work. These three imperial metrological standardizations commit to the making of a world less livable for some forms of life than for others.

In the Green Revolution era, the cultivar as a whole was the unit that polarized most efforts to produce both exact science (controlled experiment with homogeneous 'material'), productive inputs (elite cultivars), and ownable and tradeable commodities ('Distinct Uniform and Stable' cultivars). With the 'biotech revolution', the gene and its practical manipulation into specific transgenic constructs has become the unit of scientific intervention, ownership, trade and endless 'improvement'. Here, the standardization of GMO detection techniques has become a major, contested stake for the control of the global flow of patented transgenes in world markets and agroecosystems. The global biotech enterprise keeps grinding away in the laboratories of power, externalizing and denying recalcitrant, non-compliant Mexican actors and processes, and reducing global historical and political struggles to 'respect for sound science'. Meanwhile, the more modest agents of a non-imperialist world struggle to maintain 28 
their very existence within a more accommodating ontology, a more plural world that could allow multiple nature-cultures to thrive.

\section{Acknowledgements}

This research was carried within the BIOTEK project (ANR Grant, France) coordinated by Frederic Thomas whom we thank warmly for his support. We also thank Sheila Jasanoff for hosting one of us (CB) at Harvard University during the writing of this piece, Deborah Letourneau and Ravi Rajan at UCSC for providing us a ground for discussing a preliminary version, USDA staff for assistance in compiling submitted Biotech Risk Assessment Program projects, and all the Mexican scientists and farmers who have made this work possible and great experience.

\section{References}

Alvarez-Morales A (2002) Transgenes in maize landraces in Oaxaca: Official report on the extent and implications. The 7th international symposium on the biosafety of genetically modified organisms, Beijing, China, 13 October 2002, p.78.

Aquino P, Carrion F, Calvo R and Flores D (2001) Selected maize statistics. In: Pingali P (ed) CIMMYT 1999-2000 World Maize Facts and Trends. Mexico, 45-57.

Bellon, MR (1996) The dynamics of crop infraspecific diversity: A conceptual framework at the farmer level. Economic Botany 50(1): 26-39.

Bellon MR, Berthaud J (2004) Transgenic maize and the evolution of landrace diversity in Mexico: The importance of farmers' behavior. Plant Physiology 134(3): 883-888.

Bonneuil C (2006) Cultures épistémiques et engagement des chercheurs dans la controverse OGM. Natures Sciences Société 14(3): 257-268.

Bonneuil C (2014) Pure lines as industrial simulacra. A cultural history of genetics from Darwin to Johannsen. In: Brandt C, Müller-Wille S and Rheinberger H-J (eds) Heredity Explored: Between Public Domain and Experimental Science, 1850-1930. Cambridge, Mass: MIT Press, in press.

Bonneuil C and Fenzi M (2011) Des ressources génétiques à la biodiversité cultivée. La carrière d'un problème public mondial. Revue d'Anthropologie des Connaissances 5(2): 206233. An english version of this article is available from the authors. 
Böschen S, Kastenhofer K, Marschall L, Rust I, Soentgen J and Wehling P (2006) Scientific cultures of non-knowledge in the controversy over GMOs: The cases of molecular biology and ecology. GAIA - Ecological Perspectives for Science and Society 15(4): 294-301.

Brush SB (ed) (2000) Genes in the Field. Rome: IPGRI-IDRC.

Busch L (2011) Standards: Recipes for Reality. Cambridge, MA: MIT Press.

Secretariat of the Commission for Environmental Cooperation (CEC) (2004) Maize and Biodiversity: The Effects of Transgenic Maize in Mexico. Report for the CEC, Montréal.

Callon M, Lascoumes P and Barthe Y (2009) Acting in an Uncertain World: An Essay on Technical Democracy. Cambridge, MA: MIT Press.

Comisión Intersecretarial de Bioseguridad de los Organismos Genéticamente Modificados (CIBIOGEM) (2004) Reporte técnico acerca de la presencia de maíz transgénico en México. Unpublished official document by CIBIOGEM, Mexico.

Cleveland DA, Soleri D, Aragón-Cuevas F, Crossa J and Gepts P. (2005) Detecting (trans) gene flow to landraces in centers of crop origin: lessons from the case of maize in Mexico. Environmental Biosafety Research 4(4):197-208.

Herrera LA, Joffrey GA, Álvarez MA, Heuerta E, Arriaga L, Soberón J, Ortiz S, Aldama A, Cotero MA, Serratos JA (2002) Primer informe sobre el análisis de la presencia de máiz transgénico en Oaxaca y Puebla. Report for the Secretaría de Agricultura, Ganadería, Desarrollo Rural, Pesca y Ailmentación/Dirección General de Sanidad Vegetal/Comité Intersecretarial de Bioseguridad de Organismos Genéticamente modificados, Mexico.

Cotter J (2003) Troubled Harvest: Agronomy and Revolution in Mexico, 1880-2002. Westport, Connecticut: Praeger.

Dalton R (2008) Modified genes spread to local maize. Nature 456: 149.

Delborne JA (2008) Transgenes and transgressions: Scientific dissent as heterogeneous practice. Social Studies of Science 38(4): 509-541.

Delborne JA (2011) Constructing audiences in scientific controversy. Social Epistemology 25(1): 67-95.

CECCAM, CENAMI, Grupo ETC, CASIFOP, UNOSJO \& AJAGI (2003) La contaminación transgénica del maíz campesino en México. Article by the Documento colectivo de comunidades indígenas y campesinas de Oaxaca, Puebla, Chihuahua, Veracruz. Available at: http://www.biodiversidadla.org/layout/set/print/Principal/Secciones/Documentos/Transg enicos/La_contaminacion_transgenica_del_maiz_campesino_en_Mexico 
Doebley J (1990) Molecular evidence for gene flow among Zea species. BioScience 40(6): 443448.

Dyer GA, Serratos-Hernández JA, Huga RP, Gepts P, Piñeyro-Nelson A, Chávez A, SalinasArreortua N, Yúnez-Naude A, Edward Taylor J, Alvarez-Buylla ER (2009) Dispersal of transgenes through maize seed systems in Mexico. PLoS ONE 4(5): e5734.

Dyer GA and Taylor JE (2008) A crop population perspective on maize seed systems in Mexico. PNAS 105(2): 470-475.

Ezcurra E, Ortiz-García S and Soberón Mainero J (2002) Evidence of gene flow from transgenic maize to local varieties in mexico. In: LMOs and the Environment: Proceedings of an International Conference. Roseland CR and Organization for Economic Cooperation and Development (OECD) (eds.), Raleigh-Durham, North Carolina, 27-30 November 2001, 289295. USA: Mailwell Print Group.

Fagan J, Schoel B, Haegert A, Moore J, Beeby J (2001) Performance assessment under field conditions of a rapid immunological test for transgenic soybeans. International Journal of Food Science and Technology 36(4): 357-367.

Fitting E (2011) The Struggle for Maize: Campesinos, Workers, and Transgenic Corn in the Mexican Countryside. Durham and London: Duke University Press.

Foyer J (2010) Il Était une Fois la Bio-Révolution: Nature et Savoirs dans la Modernité Globale. Paris: Presses Universitaires de France.

Fox-Keller E (2000) The Century of the Gene. Cambridge, MA: Harvard University Press.

Hernández Xolocotzi E (ed.) (1977). Agroecosistemas de México. Chapingo, Mexico: Colegio de Postgraduados, Universidad Autónama Chapingo.

Jasanoff S (ed) (2004) States of Knowledge: The Co-Production of Science and Social Order. London and New York: Routledge.

Jasanoff S (2006) Biotechnology and empire: The global power of seeds and science. Osiris 21: 273-293.

Kaiser J (2005) Calming fears, no foreign genes found in Mexican maize. Science 309(5737): 100.

Kaplinsky N, Braun D, Lisch, D, Hay A and Hake S (2002) Maize transgene results in Mexico are artefacts. Nature 416: 601-602.

Kay LE (1993) The Molecular Vision of Life: Caltech, the Rockefeller Foundation, and the Rise of the New Biology. New York: Oxford University Press. 
Kinchy AJ (2012) Seeds, Science, and Struggle: The Global Politics of Transgenic Crops. Cambridge, MA: MIT Press.

Kleinman DL and Suryanarayanan S (2013) Dying bees and the social production of ignorance. Science, Technology \& Human Values 38(4): 492-517.

Knorr-Cetina K (1999) Epistemic Cultures: How the Sciences Make Knowledge. Cambridge: Harvard University Press.

Landavazo Gamboa DA, Guadalupe Calvillo Alba K, Espinosa Huerta E, González Morelos L, Aragón Cuevas F, Torres Pacheco I, Haracio Guzmán S, Montero Tavera V and Alejandra Mora Avilés M (2006) Caracterización molecular y biológica de genes recombinantes en maíz criollo de Oaxaca. Agricultura Técnica en México 32(3): 267-279.

Latour B (1995) The 'pedofil' of Boa Vista: A photo-philosophical montage. Common Knowledge 4(1): 144-87.

Lezaun J (2003) Policing Purity: Testing, Traceability, and the Governance of Genetically Modified Organisms. PhD Thesis, Cornell University, 2003.

MacKenzie A, Waterton C, Ellis R, Frow EK, McNally R, Busch L and Wynne B (2013) Classifying, constructing, and identifying life: standards as transformations of 'the biological.' Science, Technology and Human Values. 38(4): 701-722.

Marris E (2005) Four years on, no transgenes found in Mexican Maize. Nature 436(7052): 760.

Martinez-Soriano JPR and Leal-Klevezas DS (2000) Transgenic maize in Mexico: no need for concern. Science 287(5457): 1399-1399.

Matsuoka T, Kuribara H, Takubo K, Akiyama H, Miura H, Goda Y Kusakabe Y, Isshiki K, Toyoda $M$ and Hino A (2002) Detection of Recombinant DNA Segments Introduced to Genetically Modified Maize (Zea mays). Journal of Agriculture and Food Chemistry 50(7): 2100-2109.

National Research Council (2002) Environmental Effects of Transgenic Plants: The Scope and Adequacy of Regulation. Washington, DC: The National Academies Press.

O'Connell J (1993) Metrology: The creation of universality by the circulation of particulars. Social Studies of Science 23(1): 129-173.

Ortega-Paczka RA (1973) Variación en maíz y cambios socioeconómicos en Chiapas, Méx. 19461971. MS Thesis. Chapingo, Mexico: Colegio de Postgraduados, Universidad Autónama Chapingo. 
Ortiz-García S, Ezcurra E, Schoel B, Acevedo F, Soberón J and Snow A (2005) Absence of detectable transgenes in local landraces of maize in Oaxaca, Mexico (2003-2004). PNAS 102 (35): 12338-12343.

Perales HR, Brush SB and Qualset CO (2003) Dynamic management of maize landraces in central Mexico. Economic Botany 57(1): 21-34.

Piñeyro-Nelson A,Van Heerwaarden J, Perales HR, Serratos-Hernandez JA, Rangel A, Hufford MB, Gepts P, Garay-Arroyo A, Rivera-Bustamante R and Alvarez-Buylla E (2009a) Transgenes in Mexican maize: molecular evidence and methodological considerations for GMO detection in landrace populations. Molecular Ecology 18(4): 750-761.

Piñeyro-Nelson A,Van Heerwaarden J, Perales HR, Serratos-Hernandez JA, Rangel A, Hufford MB, Gepts P, Garay-Arroyo A, Rivera-Bustamante R and Alvarez-Buylla E (2009b) Resolution of the Mexican transgene detection controversy: error sources and scientific practice in commercial and ecological contexts. Molecular Ecology 18(20): 4145-4150.

Prakash CS (2005) Duh...No GM genes in Mexican Corn. In: AgBioworld Newsletter. Available at: http://www.agbioworld.org/newsletter_wm/index.php?caseid=archive\&newsid=2398( accessed at October 20,2011).

Pressoir G and Berthaud J (2004) Population structure and strong divergent selection shape phenotypic diversification in Maize landraces. Heredity 92(2): 95-101.

Proctor RN and Schiebinger L (eds) (2008) Agnotology: The Making and Unmaking of Ignorance Palo Alto, CA: Stanford University Press.

Quist D and Chapela I (2001) Transgenic DNA introgressed into traditional maize landraces in Oaxaca, Mexico. Nature 414(6863): 541-543.

Rabinow P (1996) Making PCR. A Story of Biotechnology. Chicago: University of Chicago Press

Scott JC (1990) Domination and the Arts of Resistance: Hidden Transcripts. New Haven CT: Yale University Press

Scott JC (1998) Seeing Like a State: How Certain Schemes to Improve the Human Condition Have Failed. New Haven, CT: Yale University Press.

Scott JC (2009) The Art of Not Being Governed: An Anarchist History of Upland Southeast Asia, New Haven, CT: Yale University Press.

Serratos JA, Willcox MC and Castillo F (eds) (1997) Gene Flow among Maize Landraces, Improved Maize and Teosinte: Implications for Transgenic Maize. Proceedings from the 
International Maize and Wheat Improvement Centre (CIMMYT) forum on 21-25 September, 1997, El Batan, Mexico: CIMMYT.

Serratos JA, López H and Carillo C (eds) (2000) Taller de maíz transgénico. Proceedings from meeting with the North American Plant Protection Organization (NAPPO), General Directorate on Plant Health (DGSV) and Comité Nacional de Bioseguridad Agrícola CNBA on 13-16 October, 1997. Mexico.

Serratos JA, Gómez-Olivares J-L, Salinas-Arreortua N, Buendía-Rodríguez E, Islas-Gutiérrez F and de-Ita A (2007) Transgenic proteins in maize in the soil conservation area of federal district, Mexico. Frontiers in Ecology and the Environment 5(5): 247-252.

Shapin S (1989) The invisible technician. American Scientist 77(6): 554-563.

Shoel B and Fagan J (2009) Insufficient evidence for the discovery of transgenes in Mexican Landraces. Molecular Ecology 18(20): 4143-4144.

Star S (1991) Power, technologies, and the phenomenology of conventions: On being allergic to onions. In J Law (ed) A Sociology of Monsters: Essays on Power, Technology, and Domination, London: Routledge, 26-56.

van der Ploeg JD (1993) Potatoes and knowledge. In: Hobart M (ed) Anthropological Critique of Development: The Generation of Ignorance. London: Routledge, 177-234.

van Heerwaarden J, Ortega del Vecchyo D, Alvarez-Buylla E and Bellon M (2012) New genes in traditional seed systems: Diffusion, detectability and persistence of transgenes in a maize metapopulation. PLoS ONE 7(10): e46123.

Wainwright J and Mercer C (2011) Transnational transgenes: The political ecology of maize in Mexico. In: Peet R, Robbins P and Watts M (eds) Global Political Ecology. London and New York: Routledge, 412-430.

Walbot V (2008) Maize genome in motion. Genome Biology 9(4): 303.1-303.3.

Wynne B (1989) Frameworks of rationality in risk management: Towards the testing of naïve sociology. In: Brown J (ed) Environmental Threats: Analysis, Perception, Management. London: Frances Pinter, 33-47.

Wynne B (1992) Uncertainty and environmental learning: Reconceiving science and policy in the preventive paradigm. Global Environmental Change 2(2): 111-137.

Wynne B (1996) May the sheep safely graze? A reflexive view of the expert-lay knowledge divide. In: Lash S, Szerszynski B and Wynne B (eds) Risk, Environment and Modernity: Towards a New Ecology. London, UK and Beverley Hills, CA: Sage, 44-83. 
Wynne B (2001) Creating public alienation: Expert discourses of risk and ethics on genetically manipulated organisms. Science as Culture 10(4): 445-81

Christophe Bonneuil (http://koyre.ehess.fr/index.php?174) is a Senior researcher at the Centre A. Koyré (Cnrs \& Ehess, Paris) and at IFRIS. His research explores the changing ways of knowing and ways of governing nature in the last 150 years. He has analyzed several controversies around biotechnologies and environmental issues. He has published Gènes, pouvoirs et profits (2009, with F. Thomas), Sciences, techniques et société (2013, with P.-B. Joly) and L'événement Anthropocène (2013, with J.-B Fressoz). christophe.bonneuil@cnrs.fr

Jean Foyer (http://www.iscc.cnrs.fr/spip.php?article1136) is a sociologist at the Institut des Sciences de la Communications du CNRS. His research deals with different configurations between the environment and society, especially in Latin America and Mexico. He has published De la integración nacional al desarrollo sustentable (2011, with Eric Leonard) and Il était une fois la bio-révolution (2010). jean.foyer@cnrs.fr

Brian Wynne is at the Centre for the Study of Environmental Change, CSEC, and the Centre for Science Studies, CSS, Department of Sociology, Lancaster University, UK. His work has involved sociology, history and philosophy of scientific knowledge in public arenas, including technology and risk assessment, imaginaries of publics and science, and public encounters with what is called science and expert authority.b.wynne@lancaster.ac.uk

${ }^{1}$ USDA BRAG program data. One of us compiled all submitted projects since 1992, with kind assistance from USDA staff. 